\title{
The role of p21 in regulating mammalian regeneration
}

\author{
Larry Matthew Arthur and Ellen Heber-Katz*
}

\begin{abstract}
The MRL (Murphy Roths Large) mouse has provided a unique model of adult mammalian regeneration as multiple tissues show this important phenotype. Furthermore, the healing employs a blastema-like structure similar to that seen in amphibian regenerating tissue. Cells from the MRL mouse display DNA damage, cell cycle G2/M arrest, and a reduced level of $\mathrm{p} 21^{\mathrm{CIP}}$ /NAF. A functional role for p21 was confirmed when tissue injury in an adult p $21^{-1}$ mouse showed a healing phenotype that matched the MRL mouse, with the replacement of tissues, including cartilage, and with hair follicle formation and a lack of scarring. Since the major canonical function of p21 is part of the p53/p21 axis, we explored the consequences of $\mathrm{p} 53$ deletion. A regenerative response was not seen in a p $53^{-/-}$mouse and the elimination of p53 from the MRL background had no negative effect on the regeneration of the MRL.p53-- mouse. An exploration of other knockout mice to identify p21-dependent, p53-independent regulatory pathways involved in the regenerative response revealed another significant finding showing that elimination of transforming growth factor- $\beta 1$ displayed a healing response as well. These results are discussed in terms of their effect on senescence and differentiation.
\end{abstract}

\section{Introduction}

Recently, we published a study demonstrating that a deletion of the gene $p 21^{C I P / W A F}$ converts a non-regenerating strain of mouse to one capable of epimorphic regeneration and has provided a unique opportunity to uncover some of the unknowns of this process in mammals. Since p21 is involved intricately in so many cellular processes, it is not clear at this time how deletion

*Correspondence: heberkatz@wistar.org

The Wistar Institute, 3601 Spruce Street, Philadelphia, PA 19104, USA of this gene results in such a healing phenotype. This review will discuss our results, how our findings relate to other studies, and speculation as to the role of p21 in regeneration.

\section{A mammalian model of regeneration, the MRL mouse}

In 1998, the MRL (Murphy Roths Large) mouse, generated from cross-breeding AKR, C3H, C57BL/6(B6), and LG strains of mice [1], was shown to be able to close ear punches without showing residual signs of injury or scarring [2]. Multiple tissues were perfectly replaced, cartilage re-grew, and hair follicles reappeared. Furthermore, this type of perfect multi-tissue healing, known as epimorphic regeneration, occurred with the formation of a blastema-like structure that had been shown to be key to amphibian limb regeneration [3-5]. This phenomenon had earlier been seen in rabbit ear holes [6-8], and furthermore, a blastema-derived structure had also been described during antler re-growth [9]. The amphibian and mammalian ear hole regeneration processes have many features in common, including rapid reepithelialization of the wound [2], elimination of the basement membrane between the epidermal and dermal tissue layers $[10,11]$, blastema formation, re-growth of cartilage and hair follicles, and scarless healing $[2,12,13]$. However, the existence of an inbred mouse model allowed this process to be genetically approachable. It was also determined that one of the strains used to generate the MRL mouse, the LG/J mouse, contributed the regeneration phenotype [14].

Ear hole closure has lent itself exceedingly well to genetic studies as this is a wound that is easy to access and measure and has proven to be a highly quantitative trait [15-17]. Recently, making use of an advanced intercross line (LG, SM F34 AIL) employing 1,200 mice and 3,600 single nucleotide polymorphisms [18], 18 quantitative trait loci were identified for ear hole closure with small intervals from 0.661 to $7.141 \mathrm{Mb}$ in length, which essentially reduced the healing intervals $10-$ to 50-fold from studies using F2 mice [15] (JM Cheverud et al., manuscript in preparation). This has allowed a more focused analysis of candidate genes. Further narrowing of 
these loci and testing of candidates using gene knockouts should lead to the final identification of these genes.

Besides ear hole closure, multiple organ and injury systems have extended the MRL mouse's unusual healing properties. They include regenerative studies in the heart [19-21], central nervous system stem cells and tissue [22-24], cartilage [25], cornea [26], digit [27,28] and myometrial healing [29]. Dorsal skin wound healing, which involves skin contracture, has been reported to be no different or even worse in the MRL compared to controls $[30,31]$. However, a recent study shows that if the wound has a syngeneic or allogenic skin transplant, the MRL shows far better healing than the control [32]. One possible explanation for the healing differences in different systems is that wound contracture, involving myofibroblasts or cells expressing Sma-1 (smooth muscle actin), known to be responsible for scarring, is different in the MRL. Preliminary studies suggest this [33] (D Gourevitch, K Bedelbaeva, unpublished data). Thus, the wound site and type of wound need to be considered in the MRL's healing properties.

\section{G2/M cell cycle accumulation of regenerating cells}

The cells derived from the ear of regenerating and nonregenerating mice also show significant differences from each other and represent what is seen in vivo. MRL fibroblast-like cells from uninjured ears display an uncommon metabolic profile characteristic of an embryonic-type aerobic glycolysis, a feature of the adult MRL mouse itself, versus the more common metabolic state - oxidative phosphorylation - as seen in the B6 mouse [34]. These cells express stem cell markers similar to adult MRL tissue that expresses these markers [34]. In a separate study, cells derived from the injured MRL ear blastema expressed stem cell markers as found in vivo [35] and displayed highly proliferative and migratory responses in vitro similar to human multipotential progenitor cells in this study [36].

The rapid growth rate of fibroblast-like cells from the uninjured MRL ear was noted early on and examination of cell cycle regulation comparing healer MRL to nonhealer B6 cells showed that the healer cells had an unusual accumulation of cells in G2/M [33]. A likely explanation of such $\mathrm{G} 2 / \mathrm{M}$ accumulation or potential arrest was a DNA damage response and this was supported by an increased p53 response in the MRL [33] and confirmed with data showing that foci of $\gamma \mathrm{H} 2 \mathrm{AX}$ and TopBP1, a phosphorylated histone and a protein recruited to sites of DNA damage, respectively, were highly increased in MRL cells and tissue [33]. DNA damage itself was tested using the comet assay and found in nearly $90 \%$ of healer cells compared to $5 \%$ of non-healer cells, showing both single-strand and double-strand breaks. Furthermore, the DNA repair protein RAD51 was increased in healer cells, suggesting that error-free homologous recombination was being used [33]. The cause of the DNA damage is still unclear, but the lack of the cell cycle protein $\mathrm{p} 21^{\text {Cip } / / \text { Wafl }}$ discussed below suggests a replicative stress mechanism.

These results agree with many reports in the literature that $\mathrm{G} 2 / \mathrm{M}$ accumulation is associated with regeneration in examples ranging from hydra [37] to amphibian [38] to mammalian liver $[39,40]$. The literature also shows that cells undergoing blastema formation synthesize DNA but have a low mitotic index, indicating an accumulation between S and M and implicating G2 [41-47]. Multiple in vitro studies have carefully explored cell cycle arrest and the factors involved in the re-entry of cells into $S$ phase of the cell cycle and accumulation in G2, as seen in multinucleated muscle myotubes and myofibers from regenerating amphibian limbs [48], in multinucleated mammalian myotubes generated from rat $\mathrm{C} 2 \mathrm{C} 12$ cell line myoblasts, and in primary mouse myoblasts [49-51].

In MRL ear-derived cells, the fact that DNA damage was so widespread made one question why an accumulation of cells was seen in G2/M and not in G1/S. This led to an examination of G1 cell cycle regulatory proteins. The first to be examined, the CDKN1A or $\mathrm{p} 21^{\text {Cip } 1 / \text { Wafl }}$ protein [52], was found to be repressed in these cultured cells. Examination of similar ear-derived cells from a CDKN1A-deficient mouse [33] showed the same phenotype as MRL cells with increased DNA damage, $\gamma \mathrm{H} 2 \mathrm{AX}$ expression, and G2/M accumulation. But most striking was the fact that this mouse could fully close earhole injuries at least as well as the MRL mouse [33]. There have been other mice that possess the ability to partially heal ear holes, including nude mice [53], mice expressing the transgene $A G F$ (angiopoietin-related growth factor) in keratinocytes [54], and mice selected for inflammatory potential [55]. However, what was surprising to us was that deletion of this single gene, as predicted from our in vitro ear dermal cell model, could actually result in the full MRL epimorphic regeneration phenotype.

\section{The role of $\mathrm{p}_{21} \mathrm{CIP}^{1 / \mathrm{Waf} 1}$, regeneration, and the retinoblastoma protein}

Earlier studies have examined the role of p21 in regeneration of the mammalian liver. Gene expression of p21 plays a role in hepatic regeneration by both p53dependent and p53-independent control mechanisms [56]. Transgenic mice that over-express $\mathrm{p} 21$ produced large polyploid nuclei in a portion of the hepatocytes and the regenerative capacity of the livers was halted [57]. Over-expression of STAT-3 with resulting p21 upregulation impairs regeneration in fatty livers [58]. Consistent with this picture, repression of the $\mathrm{p} 53 / \mathrm{p} 21$ pathway was shown to enhance liver regeneration [59]. Such studies parallel our recent findings [33]. 
The overall understanding of the functions of p21 can be quite overwhelming considering the complexity of functions in which this protein has been implicated. p21 is involved in the response to cellular stresses, such as DNA damage, oxidative stress, cytokines, mitogens, tumor viruses, and anti-cancer agents, and can have tumor suppressive activities and oncogenic capabilities depending on the cell type and context [60,61]. For example, p21 is transcriptionally regulated by $\mathrm{p} 53$ for tumor suppressor activity and as an inhibitor of cell cycle progression through the inhibition of cyclin-dependent kinase (CDK)cyclin complexes and proliferating cell nuclear antigen, which can lead to differentiation, apoptosis, or senescence. Increasing this complexity is the fact that $\mathrm{p} 21$ can regulate gene expression and other cellular events, such as autophagy and a DNA damage repair response, through protein-protein interactions that depend on the cell type, subcellular localization, expression levels, protein stability, and post-translational modifications [62-66].

So which of these functions are involved in the regeneration phenotype seen in the $\mathrm{p} 21^{-/}$mice? Some indication may come from in vitro studies in other regenerating systems. For example, adult urodele amphibians can regenerate limbs through a process that involves loss of differentiation markers, cell cycle reentry, proliferation, formation of a blastema, and differentiation into adult tissue [12]. In an amphibian in vitro model of skeletal muscle regeneration, retinoblastoma $(\mathrm{Rb})$ protein plays a predominant role in cell cycle reentry through phosphorylation by CDK4/6 [67]. This process requires serum to stimulate entry of the quiescent nuclei of multinuclear myotubes into S-phase with a serum-derived thrombin-activated factor being necessary for $\mathrm{Rb}$ hyperphosphorylation, resulting in its 'inactivation' [48,68]. These cells enter $S$ phase but arrest and do not separate into single cells, which would allow further progression of the cell cycle through mitosis. However, there are conflicting reports about mammalian cells. Myotubes from an $\mathrm{Rb}^{-/}$mouse are capable of cell cycle re-entry and show DNA synthesis upon serum stimulation but no mitosis in one study [50] but no cell cycle re-entry in another [51]. In a separate study using mammalian myotubes generated from the rat $\mathrm{C} 2 \mathrm{C} 12$ myoblast line, newt regeneration blastema extract led to myotube cellularization to smaller myotubes and proliferating mononucleate cells, suggesting de-differentiation with reduced expression of mature muscle cell markers [49]. In addition, a recent report using primary myoblasts [69] suggests that another factor in addition to $\mathrm{Rb}, \mathrm{p} 19^{\text {arf }}$, must be inactivated for cell cycle re-entry and de-differentiation in postmitotic mammalian muscle. The tumor suppressor protein p19 arf acts as a regeneration suppressor and is not found in regenerative vertebrates, suggesting that it has interesting potential as a key to mammalian regeneration. Thus, $\mathrm{Rb}$ inactivation has been shown to be important in both amphibian and mammalian regeneration in vitro.

The p21 protein, its major role being a CDK inhibitor found on chromosome 17 in the mouse, is known to block proliferation by preventing the phosphorylation of $\mathrm{Rb}$ and the transcription of cell cycle-regulated proproliferative proteins. The p21 protein binds to cyclinCDK (2/4) complexes, not allowing them to function as kinases. They in turn cannot phosphorylate $\mathrm{Rb}$, which remains bound to E2F, a transcription factor responsible for proliferation, effectively blocking E2F function. Thus, p21 activity directly leads to suppression of cell cycle transit and the loss of p21 should promote E2F activity, lead to enhanced DNA synthesis and potentially to dedifferentiation. $\mathrm{Rb}$ function, then, in the studies above should be directly affected by $\mathrm{p} 21$ activity.

Not surprisingly, p53 and p21 have been shown to prevent the transition from fibroblasts to induced pluripotent stem cells [70-72]. The level of de-differentiation in the $\mathrm{p} 21^{-/}$mouse is being further explored, although we have previously reported that stem cell markers are over-expressed in MRL tissue [34].

\section{The role of $\mathrm{p} 53$, senescence, and transforming growth factor- $\beta$ in regeneration}

As mentioned above, we found that p53 was up-regulated in MRL mouse ears, though p21 was absent. Is there a role for $\mathrm{p} 53$ in regeneration? Unlike the $\mathrm{p} 21^{-1-}$ mouse, which is a complete regenerator, $\mathrm{p} 53^{-1-}$ mice show no regenerative capacity [73]. This finding established a p53independent function of $\mathrm{p} 21$ that is important for regeneration. However, MRL.p53 ${ }^{-}$crosses showed not only healing rates similar to or better than the MRL itself but also showed enhanced differentiation in the form of increased chondrogenesis and adipogenesis [73]. The major role played by p53 as the 'guardian' of the genome is due to its ability to respond to DNA damage and cellular stress by inhibiting cell cycle progression and then regulating DNA repair, cell cycle control, apoptosis, differentiation, autophagy induction, and senescence. It is not clear which of these functions or lack thereof could be responsible for the enhanced differentiation observed in MRL.p53 $3^{-1-}$ mice [64,71,74-79]. One study suggests that removal of p53 allows for an accumulation of cells with elevated levels of DNA damage (on a repair-deficient background mouse), which delays hair follicle renewal and regeneration [80,81]. However, we observed hair follicle formation in our MRL/p53 $3^{--}$mice [73]. Further regeneration studies on different tissue types need to be performed in order to determine the role of p53 in regeneration.

One potential area of interest are the roles of p21 and p53 in both differentiation and cellular senescence at 
wound sites. It has been shown that elimination of p21 in mouse stem cells with dysfunctional telomeres, a marker for senescence induction, increases stem cell function and the life span of these mice without an increase in cancer formation, providing a direct role for $\mathrm{p} 21$ in both stem cell differentiation and senescence [82]. One direct link for p21 in differentiation and senescence is suppression by the Twist proteins, major regulators of embryogenesis [83]. The Twist proteins inhibit p21 in a p53independent manner and promote epithelial-mesenchymal transition and suppress cellular senescence [84].

The two major pathways for inducing senescence in cells of multiple tissues are p53/p21 [85-91] and p16 ink4a [75,92-95]. In an earlier paper, we suggested that senescence was not a factor in MRL regeneration because of the lack of p53 requirement [73]. However, there is, in fact, evidence that $\mathrm{p} 21$ can induce senescence in the absence of p53 [87,96-98] as well as p53-mediated p21independent activation of senescence [99-101]. It has been suggested that reactive oxygen species are necessary to maintain the senescence phenotype and that both $\mathrm{p} 16$ and p21 are involved [99,102,103]. Actually, we previously reported that reactive oxygen species levels are decreased in the MRL mouse [34], consistent with an aerobic glycolytic metabolism, which argues against senescence playing a functional role. In addition, the protein RhoD, which is required for transformation by the oncogenic protein Ras, is responsible for suppressing p21 induction and subsequent senescence $[104,105]$. The gene ID1 has been shown to repress HRAS-mediated senescence in the presence of increased amounts of p21 [106], arguing the other way. Recently, a publication showed that the matricellular protein $\mathrm{CCN} 1$, which is expressed at the sites of wounds, induces senescence through p53 and actually helps to prevent fibrosis during tissue repair [107]. In this case, however, the healing is tissue repair with scarring and not blastema-induced scarless regeneration. Thus, the connection between senescence and regeneration, and its difference compared to oncogenesis, is yet to be determined.

Another major regulator of $\mathrm{p} 21$ is transforming growth factor (TGF)- $\beta 1$, which is involved in anti-proliferation and differentiation [108]. TGF- $\beta 1$ controls proliferation, differentiation, migration, and apoptosis in embryonic and adult tissue through the Smad3 pathway [109-113]. Multiple studies in mutant mice lacking the TGF- $\beta 1 /$ Smad3 pathway have implicated a regeneration phenotype in mice: mice lacking TGF- $\beta 1$ show an increase in wound closure and epithelialization [114]; transgenic mice null for Smad3 show increased re-epithelialization and tissue renewal [115]; and Smad7 over-expression leads to Smad3 down-regulation and to enhanced liver regeneration through the TGF- $\beta / \operatorname{Smad} 3 / \mathrm{p} 21$ pathway [116]. Smad3 has been implicated as a candidate gene in our genetic mapping studies of healer MRL and parental LG mice [15]. Contrary to these results, other transgenic studies on TGF- $\beta 1$-null mice showed malfunctions in the repair of excisional back skin wounds due to altered inflammatory responses [117-119]. Our studies have shown that a TGF- $\beta 1 / \operatorname{Rag} 1$ double knockout mouse is a partial healer [73]. An interesting fact is that TGF- $\beta 1$ enhances Sma-1 production and myofibroblasts associated with scarring [120] and reduces regenerative healing, whereas the TGF- $\beta$ isoform TGF- $\beta 3$ enhances scar-free healing [121].

\section{Conclusions}

The MRL mouse is the first genetically dissectible and molecularly tractable mammalian model of regeneration of multiple tissues in a single organism. It establishes the fact that regenerative capacity has not been lost to mammals through evolution but remains as a cryptic trait, which can be activated by the deletion of a single gene, $p 21$. Thus, the $\mathrm{p} 21$-null mouse now should become a 'single gene' standard model for mammalian regenerative studies.

The lack of p21 may act to enhance the regenerative response in various ways. It could alter DNA damage and checkpoint responses, leading to enhanced proliferation. It could reduce TGF- $\beta$ signaling, leading to reduced scar formation, and alter differentiation patterns. It could lead to lack of senescence and reduced cytokine responses. It could support progenitor cell stability as seen in induced pluripotent stem cell formation.

Besides determining exactly which function of $\mathrm{p} 21$ and its absence is responsible for enhanced ear hole closure, it will also be important to define the critical pathways in the MRL mouse that actually lead to p21 down-regulation and regeneration.

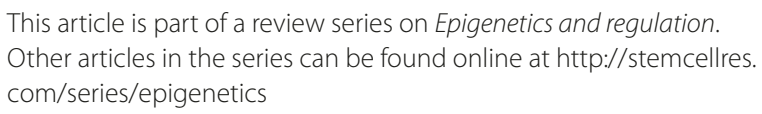

Abbreviations

CDK, cyclin-dependent kinase; MRL, Murphy Roths Large; Rb, retinoblastoma; Sma-1, smooth muscle actin; TGF, transforming growth factor.

\section{Competing interests}

The authors declare that they have no competing interests.

\section{Acknowledgements}

These studies were supported by the FM Kirby Foundation, G Harold and Leila Y Mathers Foundation, and an NIH ARRA grant from NIGMS. The work was also supported by an NCl Cancer Center Grant (P30 CA10815). LMA was supported by the Training Program Grant in Basic Cancer Biology 5T32CA09171. We would like to thank Larry O Arthur, Andrew Snyder, and John Leferovich for their useful comments and insight.

Published: 29 June 2011 


\section{References}

1. Murphy ED: Lymphoproliferation (Ipr) and other single-locus models for murine lupus. In Immunologic Defects in Laboratory Animals. Volume 2. Edited by Gershwin ME, Merchant B. New York: Plenum Publishing Corp.; 1981:143-173.

2. Clark LD, Clark RK, Heber-Katz E: A new murine model for mammalian wound repair and regeneration. Clin Immunol Immunopathol 1998, 88:35-45

3. Stocum DL: The urodele limb regeneration blastema. Determination and organization of the morphogenetic field. Differentiation 1984, 27:13-28.

4. Brockes JP, Kumar A: Appendage regeneration in adult vertebrates and implications for regenerative medicine. Science 2005, 310:1919-1923.

5. Gardiner DM, Bryant SV: Molecular mechanisms in the control of limb regeneration: the role of homeobox genes. Int J Dev Biol 1996, 40:797-805

6. Goss RJ, Grimes LN: Tissue interactions in the regeneration of rabbit ear holes. Am Zool 1975, 12:151-157.

7. Price J, Faucheux C, Allen S: Deer antlers as a model of mammalian regeneration. Curr Top Dev Bio/ 2005, 67:1-48

8. Kierdorf $\mathrm{U}, \mathrm{Kierdorf} \mathrm{H}$ : Deer antlers- a model of mammalian appendage regeneration: an extensive review. Gerontology 2011, 57:53-65.

9. Goss RJ: Tissue differentiation in regenerating antlers. Biol Deer Production 1985, 22:229-238.

10. Gourevitch D, Clark L, Chen P, Seitz A, samulewicz SJ, Heber-Katz E: Matrix metalloproteinase activity correlates with blastema formation in the regenerating MRL mouse ear hole model. Dev Dyn 2003, 226:377-387.

11. Stocum DL, Crawford K: Use of retinoids to analyze the cellular basis of positional memory in regenerating amphibian limbs. Biochem Cell Biol 1987, 65:750-761.

12. Nye HL, Cameron JA, Chernoff EA, Stocum DL: Regeneration of the urodele limb: a review. Dev Dyn 2003, 226:280-294.

13. Brockes JP: Amphibian limb regeneration: rebuilding a complex structure. Science 1997, 276:81-87.

14. Kench JA, Russell DM, Fadok VA, Young SK, Worthen GS, Jones-Carson J, Henson JE, Nemazee D: Aberrant wound healing and TGF-beta production in the autoimmune-prone MRL/+ mouse. Clin Immunol 1999, 92:300-310.

15. Blankenhorn E, Bryan G, Kossenkov A, Clark L, Zhang XM, Chang C, Horng W Pletscher L, Cheverud J, Showe L, Heber-Katz E: Genetic loci that regulate healing and regeneration in LG/J and SM/J mice. Mamm Genome 2009, 20:720-733

16. Heber-Katz E, Chen P, Clarck L, Zhang X-M, Troutman S, Blankenhorn EP. Regeneration in MRL mice: further genetic loci controlling the ear hole closure trait using MRL and M.m. Castaneus mice. Wound Repair Regen 2004, 12:384-392.

17. Yu H, Mohan S, Masinde G, Baylink D: Mapping the dominant wound healing and soft tissue regeneration QTL in MRL x CAST. Mamm Genome 2005, 16:918-924.

18. Norgard E, Lawson H, Pletscher L, Wang B, Brooks V, Wolf J, Cheverud J: Genetic factors and diet affect long-bone length in the F34 LG,SM advanced intercross. Mamm Genome 2011, 22:178-196.

19. Leferovich JM, Bedelbaeva K, Samulewicz S, Zhang XM, Zwas D, Lankford EB, Heber-Katz E: Heart regeneration in adult MRL mice. Proc Natl Acad Sci U SA 2001, 98:9830-9835

20. Haris Naseem R, Meeson AP, Michael DiMaio J, White MD, Kallhoff J, Humphries C, Goetsch SC, De Windt LJ, Williams MA, Garry MG, Garry DJ: Reparative myocardial mechanisms in adult C57BL/6 and MRL mice following injury. Physiol Genomics 2007, 30:44-52

21. Alfaro MP, Pagni M, Vincent A, Atkinson J, Hill MF, Cates J, Davidson JM, Rottman J, Lee E, Young PP: The Wnt modulator sFRP2 enhances mesenchymal stem cell engraftment, granulation tissue formation and myocardial repair. Proc Natl Acad Sci U S A 2008, 105:18366-18371.

22. Baker KL, Daniels SB, Lennington JB, Lardaro T, Czap A, Notti RQ, Cooper O, Isacson O, Frasca S, Conover JC: Neuroblast protuberances in the subventricular zone of the regenerative MRL/MpJ mouse. J Comp Neurol 2006, 498:747-761.

23. Thuret S, Toni N, Aigner S, Yeo GW, Gage FH: Hippocampus-dependent learning is associated with adult neurogenesis in MRL/MpJ mice. Hippocampus 2009, 19:658-669.

24. Balu DT, Hodes GE, Anderson BT, Lucki I: Enhanced sensitivity of the MRL/ $\mathrm{MpJ}$ mouse to the neuroplastic and behavioral effects of chronic antidepressant treatments. Neuropsychopharmacology 2009, 34:1764-1773.

25. Fitzgerald J, Rich C, Burkhardt D, Allen J, Herzka AS, Little CB: Evidence for articular cartilage regeneration in MRL/MpJ mice. Osteoarthritis Cartilage 2008, 16:1319-1326.

26. Ueno M, Lyons BL, Burzenski LM, Gott B, Shaffer DJ, Roopenian DC, Shultz LD: Accelerated wound healing of alkali-burned corneas in MRL mice is associated with a reduced inflammatory signature. Invest Ophthalmol Vis Sci 2005, 46:4097-4106.

27. Chadwick RB, Bu L, Yu H, Hu Y, Wergedal JE, Mohan S, Baylink DJ: Digit tip regrowth and differential gene expression in MRL/Mpj, DBA/2, and C57BL/6 mice. Wound Repair Regen 2007, 15:275-284.

28. Gourevitch DL, Clark L, Bedelbaeva K, Leferovich J, Heber-Katz E: Dynamic changes after murine digit amputation: The MRL mouse digit shows waves of tissue remodeling, growth, and apoptosis. Wound Repair Regen 2009, 17:447-455.

29. Buhimschi CS, Zhao G, Sora N, Madri JA, Buhimschi IA: Myometrial wound healing post-cesarean delivery in the MRL/MpJ mouse model of uterine scarring. Am J Pathol 2010, 177:197-207.

30. Beare AHM, Metcalfe AD, Ferguson MWJ: Location of injury influences the mechanisms of both regeneration and repair within the MRL/MpJ mouse. J Anat 2006, 209:547-559

31. Davis TA, Amare M, Naik S, Kovalchuk AL, Tadaki D: Differential cutaneous wound healing in thermally injured MRL/MPJ mice. Wound Repair Regen 2007, 15:577-588

32. Tolba RH, Schildberg FA, Decker D, Abdullah Z, Büttner R, Minor T, Von Ruecker A: Mechanisms of improved wound healing in Murphy Roths Large (MRL) mice after skin transplantation. Wound Repair Regen 2010, 18:662-670

33. Bedelbaeva K, Snyder A, Gourevitch D, Clark L, Zhang XM, Leferovich J, Cheverud JM, Lieberman P, Heber-Katz E: Lack of p21 expression links cell cycle control and appendage regeneration in mice. Proc Natl Acad Sci U S A 2010, 107:5845-5850.

34. Naviaux RK, Le TP, Bedelbaeva K, Leferovich J, Gourevitch D, Sachadyn P Zhang XM, Clark L, Heber-Katz E: Retained features of embryonic metabolism in the adult MRL mouse. Mol Genet Metab 2009, 96:133-144.

35. Samulewicz SJ, Seitz A, Clark L, Heber-Katz E: Expression of preadipocyte factor-1(Pref-1), a delta-like protein, in healing mouse ears. Wound Repair Regen 2002, 10:215-221.

36. Reing JE, Zhang L, Myers-Irvin J, Cordero KE, Freytes DO, Heber-Katz E, Bedelbaeva K, McIntosh D, Dewilde A, Braunhut SJ, Badylak SF: Degradation products of extracellular matrix affect cell migration and proliferation. Tissue Eng Part A 2009, 15:605-614.

37. Schmidt T, David CN: Gland cells in Hydra: cell cycle kinetics and development. J Cell Sci 1986, 85:197-215.

38. Stocum DL, Cameron JA: Looking proximally and distally: 100 years of limb regeneration and beyond. Dev Dyn 2011, 240:943-968.

39. Michalopoulos GK, DeFrances MC: Liver regeneration. Science 1997, 276:60-66.

40. Celton-Morizur S, Desdouets C: Polyploidization of liver cells. Adv Exp Med Biol 2010, 2010:123-135.

41. Tassava RA, Bennett $L L$, Zitnik GD: DNA synthesis without mitosis in amputated denervated forelimbs of larval axolotls. J Exp Zoo/ 1974, 190:111-116

42. Mescher AL, Tassava RA: Denervation effects on DNA replication and mitosis during the initiation of limb regeneration in adult newts. Dev Biol 1975, 44:187-197

43. Tassava RA, Mescher AL: Mitotic activity and nucleic acid precursor incorporation in denervated and innervated limb stumps of axolotl larvae. J Exp Zool 1976, 195:253-262.

44. McCullough WD, Tassava RA: Determination of the blastema cell cycle in regenerating limbs of the larval axolotl, Ambystoma mexicanum. Ohio J Sci 1976, 76:63-65

45. Tassava RA, McCullough WD: Neural control of cell cycle events in regenerating salamander limbs. Am Zool 1978, 18:843-854.

46. Maden M: Neurotrophic control of the cell cycle during amphibian limb regeneration. J Embryol Exp Morphol 1978, 48:169-175.

47. Tassava RA, Garling DJ: Regenerative responses in larval axolotl limbs with skin grafts over the amputation surface. J Exp Zool 1979, 208:97-110.

48. Tanaka EM, Drechsel DN, Brockes JP: Thrombin regulates S-phase re-entry by cultured newt myotubes. Curr Biol 1999, 9:792-799.

49. McGann CJ, Odelberg SJ, Keating MT: Mammalian myotube dedifferentiation induced by newt regeneration extract. Proc Natl Acad SCi USA 2001, 98:13699-13704 
50. Schneider JW, Gu W, Zhu L, Mahdavi V, Nadal-Ginard B: Reversal of terminal differentiation mediated by p107 in Rb-/- muscle cells. Science 1994, 264:1467-1471

51. Huh MS, Parker MH, Scimè A, Parks R, Rudnicki MA: Rb is required for progression through myogenic differentiation but not maintenance of terminal differentiation. J Cell Bio/ 2004, 166:865-876.

52. El Deiry WS, Tokino T, Velculescu VE, Levy DB, Parsons R, Trent JM, Lin D, Mercer WE, Kinzler KW, Vogelstein B: WAF1, a potential mediator of p53 tumor suppression. Cell 1993, 75:817-825.

53. Gawronska-Kozak B: Regeneration in the ears of immunodeficient mice: identification and lineage analysis of mesenchymal stem cells. Tissue Eng 2004, 10:1251-1265

54. Oike Y, Yasunaga K, Ito Y, Matsumoto Si, Maekawa H, Morisada T, Arai F, Nakagata N, Takeya M, Masuho Y, Suda T: Angiopoietin-related growth factor (AGF) promotes epidermal proliferation, remodeling, and regeneration. Proc Natl Acad Sci U S A 2003, 100:9494-9499.

55. De Franco M, Carneiro P, Peters L, Vorraro F, Borrego A, Ribeiro O, Starobinas N, Cabrera W, Ibanez O: Slc11a1 (Nramp1) alleles interact with acute inflammation loci to modulate wound-healing traits in mice. Mamm Genome 2007, 18:263-269.

56. Albrecht JH, Meyer AH, Hu MY: Regulation of cyclin-dependent kinase inhibitor p21WAF1/Cip1/Sdi1 gene expression in hepatic regeneration. Hepatology 1997, 25:557-563.

57. Wu H, Wade M, Krall L, Grisham J, Xiong Y, Van Dyke T: Targeted in vivo expression of the cyclin-dependent kinase inhibitor p21 halts hepatocyte cell-cycle progression, postnatal liver development and regeneration. Genes Dev 1996, 10:245-260.

58. Torbenson M, Yang SQ, Liu HZ, Huang J, Gage W, Diehl AM: STAT-3 overexpression and p21 up-regulation accompany impaired regeneration of fatty livers. Am J Pathol 2002, 161:155-161.

59. Stepniak E, Ricci R, Eferl R, Sumara G, Sumara I, Rath M, Hui L, Wagner EF: c-Jun/AP-1 controls liver regeneration by repressing p53/p21 and p38 MAPK activity. Genes Dev 2006, 20:2306-2314.

60. Weiss RH: p21Waf1/Cip1 as a therapeutic target in breast and other cancers. Cancer Cell 2003, 4:425-429.

61. Cazzalini O, Scovassi Al, Savio M, Stivala LA, Prosperi E: Multiple roles of the cell cycle inhibitor p21CDKN1A in the DNA damage response. Mutat Res 2010, 704:12-20.

62. Jung YS, Qian Y, Chen X: Examination of the expanding pathways for the regulation of p21 expression and activity. Cell Signal 2010, 22:1003-1012.

63. Xiong Y, Hannon GJ, Zhang H, Casso D, Kobayashi R, Beach D: p21 is a universal inhibitor of cyclin kinases. Nature 1993, 366:701-704.

64. El Deiry WS: p21/p53, cellular growth control and genomic integrity. Curr Top Microbiol Immunol 1998, 227:121-137.

65. Abbas T, Dutta A: p21 in cancer: intricate networks and multiple activities. Nat Rev Cancer 2009, 9:400-414.

66. Gartel AL: p21WAF1/CIP1 and cancer: A shifting paradigm? BioFactors 2009, 35:161-164

67. Tanaka EM, Gann AAF, Gates PB, Brockes JP: Newt myotubes reenter the cell cycle by phosphorylation of the retinoblastoma protein. J Cell Biol 1997 136:155-165.

68. Straube WL, Tanaka EM: Reversibility of the differentiated state: regeneration in amphibians. Artif Organs 2006, 30:743-755.

69. Pajcini KV, Corbel SY, Sage J, Pomerantz JH, Blau HM: Transient inactivation of $\mathrm{Rb}$ and ARF yields regenerative cells from postmitotic mammalian muscle. Cell Stem Cell 2010, 7:198-213.

70. Hanna J, Saha K, Pando B, van Zon J, Lengner CJ, Creyghton MP, van Oudenaarden A, Jaenisch R: Direct cell reprogramming is a stochastic process amenable to acceleration. Nature 2009, 462:595-601.

71. Hong H, Takahashi K, Ichisaka T, Aoi T, Kanagawa O, Nakagawa M, Okita K, Yamanaka S: Suppression of induced pluripotent stem cell generation by the p53/p21 pathway. Nature 2009, 460:1132-1135.

72. Yamanaka S: A fresh look at iPS cells. Cell 2009, 137:13-17.

73. Arthur LM, Demarest RM, Clark L, Gourevitch D, Bedelbaeva K, Anderson R, Snyder A, Capobianco AJ, Lieberman P, Feigenbaum L, Heber-Katz E: Epimorphic regeneration in mice is p53-independent. Cell Cycle 2010, 9:3667-3673.

74. El Deiry WS: Regulation of p53 downstream genes. Semin Cancer Biol 1998 , 8:345-357.

75. Beausejour CM, Krtolica A, Galimi F, Narita M, Lowe SW, Yaswen P, Campisi J: Reversal of human cellular senescence: roles of the p53 and p16 pathways. EMBO J 2003, 22:4212-4222

76. Sheahan S, Bellamy CO, Treanor L, Harrison DJ, Prost S: Additive effect of p53, p21 and Rb deletion in triple knockout primary hepatocytes. Oncogene 2003, 23:1489-1497.

77. Kuribayashi K, El Deiry WS: Regulation of programmed cell death by the p53 pathway. Adv Exp Med Bio/ 2007, 615:201-221.

78. Vousden $\mathrm{KH}$, Prives $\mathrm{C}$ : Blinded by the light: the growing complexity of $\mathrm{p} 53$. Cell 2009, 137:413-431.

79. Maiuri MC, Galluzzi L, Morselli E, Kepp O, Malik SA, Kroemer G: Autophagy regulation by p53. Curr Opin Cell Biol 2010, 22:181-185.

80. Ruzankina Y, Schoppy DW, Asare A, Clark CE, Vonderheide RH, Brown EJ: Tissue regenerative delays and synthetic lethality in adult mice after combined deletion of Atr and Trp53. Nat Genet 2009, 41:1144-1149.

81. Schoppy DW, Ruzankina Y, Brown EJ: Removing all obstacles: a critical role for p53 in promoting tissue renewal. Cell Cycle 2010, 9:1313-1319.

82. Choudhury AR, Ju Z, Djojosubroto MW, Schienke A, Lechel A, Schaetzlein S, Jiang H, Stepczynska A, Wang C, Buer J, Lee HW, von Zglinicki T, Ganser A, Schirmacher $\mathrm{P}$, Nakauchi H, Rudolph KL: Cdkn1a deletion improves stem cell function and lifespan of mice with dysfunctional telomeres without accelerating cancer formation. Nat Genet 2007, 39:99-105.

83. Ansieau S, Bastid J, Doreau A, Morel AP, Bouchet BP, Thomas C, Fauvet F, Puisieux I, Doglioni C, Piccinin S, Maestro R, Voeltzel T, Selmi A, ValsesiaWittmann S, Caron de Fromentel C, Puisieux A: Induction of EMT by twist proteins as a collateral effect of tumor-promoting inactivation of premature senescence. Cancer Cell 2008, 14:79-89.

84. Smit MA, Peeper DS: Deregulating EMT and senescence: double impact by a single twist. Cancer Cell 2008, 14:5-7.

85. Zhang X, Li J, Sejas DP, Pang Q: The ATM/p53/p21 pathway influences cell fate decision between apoptosis and senescence in reoxygenated hematopoietic progenitor cells. J Biol Chem 2005, 280:19635-19640.

86. Lee AC, Fenster BE, Ito H, Takeda K, Bae NS, Hirai T, Yu ZX, Ferrans VJ, Howard $\mathrm{BH}$, Finkel T: Ras proteins induce senescence by altering the intracellular levels of reactive oxygen species. J Bio/ Chem 1999, 274:7936-7940.

87. Fang L, Igarashi M, Leung J, Sugrue MM, Lee SW, Aaronson SA: p21Waf1/ Cip1/Sdi1 induces permanent growth arrest with markers of replicative senescence in human tumor cells lacking functional p53. Oncogene 1999, 18:2789-2797.

88. Wang Y, Blandino G, Givol D: Induced p21 waf expression in $\mathrm{H} 1299$ cell line promotes cell senescence and protects against cytotoxic effect of radiation and doxorubicin. Oncogene 1999, 18:2643-2649.

89. Dirac AM, Bernards R: Reversal of senescence in mouse fibroblasts through lentiviral suppression of p53. J Biol Chem 2003, 278:11731-11734.

90. Xue W, Zender L, Miething C, Dickins RA, Hernando E, Krizhanovsky V, Cordon-Cardo C, Lowe SW: Senescence and tumour clearance is triggered by p53 restoration in murine liver carcinomas. Nature 2007, 445:656-660.

91. Coppe JP, Patil CK, Rodier F, Sun Y, Munoz DP, Goldstein J, Nelson PS, Desprez PY, Campisi J: Senescence-associated secretory phenotypes reveal cellnonautonomous functions of oncogenic RAS and the p53 tumor suppressor. PLoS Biol 2008, 6:e301

92. Vijayachandra K, Higgins W, Lee J, Glick A: Induction of p16ink4a and p19ARF by TGFbeta1 contributes to growth arrest and senescence response in mouse keratinocytes. Mol Carcinog 2009, 48:181-186.

93. Dai $C Y$, Enders GH: p16 INK4a can initiate an autonomous senescence program. Oncogene 2000, 19:1613-1622.

94. Takahashi A, Ohtani N, Yamakoshi K, lida S, Tahara H, Nakayama K, Nakayama $\mathrm{Kl}$, Ide T, Saya H, Hara E: Mitogenic signalling and the p16INK4a-Rb pathway cooperate to enforce irreversible cellular senescence. Nat Cell Biol 2006 , 8:1291-1297.

95. Takahashi A, Ohtani N, Hara E: Irreversibility of cellular senescence: dual roles of p16INK4a/Rb-pathway in cell cycle control. Cell Division 2007, 2:10.

96. Lin HK, Chen Z, Wang G, Nardella C, Lee SW, Chan CH, Yang WL, Wang J, Egia A, Nakayama Kl, Cordon-Cardo C, Teruya-Feldstein J, Pandolfi PP: Skp2 targeting suppresses tumorigenesis by Arf-p53-independent cellular senescence. Nature 2010, 464:374-379.

97. Aliouat-Denis CcM, Dendouga N, Van den Wyngaert I, Goehlmann H, Steller U, van de Weyer I, Van Slycken N, Andries L, Kass S, Luyten W, Janicot M, Vialard JE: p53-independent regulation of p21Waf1/Cip1 expression and senescence by Chk2. Mol Cancer Res 2005, 3:627-634.

98. Brown JP, Wei W, Sedivy JM: Bypass of senescence after disruption of p21CIP1/WAF1 gene in normal diploid human fibroblasts. Science 1997, 277:831-834 
99. Macip S, Igarashi M, Fang L, Chen A, Pan ZQ, Lee SW, Aaronson SA: Inhibition of p21-mediated ROS accumulation can rescue p21-induced senescence. EMBO J 2002, 21:2180-2188.

100. Pantoja C, Serrano M: Murine fibroblasts lacking p21 undergo senescence and are resistant to transformation by oncogenic Ras. Oncogene 1999, 18:4974-4982.

101. Castro ME, Guijarro MdV, Moneo V, Carnero A: Cellular senescence induced by $\mathrm{p} 53$-ras cooperation is independent of $\mathrm{p} 21$ waf1 in murine embryo fibroblasts. J Cell Biochem 2004, 92:514-524.

102. Fiorentino FP, Symonds CE, Macaluso M, Giordano A: Senescence and p130/ Rbl2: a new beginning to the end. Cell Res 2009, 19:1044-1051.

103. Passos JF, Nelson G, Wang C, Richter T, Simillion C, Proctor CJ, Miwa S, Olijslagers S, Hallinan J, Wipat A, Saretzki G, Rudolph KL, Kirkwood TBL, von Zglinicki T: Feedback between p21 and reactive oxygen production is necessary for cell senescence. Mol Syst Biol 2010, 6:347.

104. Khosravi-Far R, Solski PA, Clark GJ, Kinch MS, Der CJ: Activation of Rac1, $\mathrm{RhoA}$, and mitogen-activated protein kinases is required for Ras transformation. Mol Cell Biol 1995, 15:6443-6453.

105. Qiu RG, Chen J, McCormick F, Symons M: A role for Rho in Ras transformation. Proc Natl Acad Sci U S A 1995, 92:11781-11785.

106. Swarbrick A, Roy E, Allen T, Bishop JM: Id1 cooperates with oncogenic Ras to induce metastatic mammary carcinoma by subversion of the cellular senescence response. Proc Natl Acad Sci U S A 2008, 105:5402-5407.

107. Jun Jl, Lau LF: The matricellular protein CCN1 induces fibroblast senescence and restricts fibrosis in cutaneous wound healing. Nat Cell Biol 2010, 12:676-685.

108. Moustakas A, Pardali K, Gaal A, Heldin CH: Mechanisms of TGF-[beta] signaling in regulation of cell growth and differentiation. Immunol Lett 2002, 82:85-91

109. Bierie B, Moses HL: Tumour microenvironment: TGF[beta]: the molecular Jekyll and Hyde of cancer. Nat Rev Cancer 2006, 6:506-520.

110. Pardali K, Moustakas A: Actions of TGF-[beta] as tumor suppressor and pro-metastatic factor in human cancer. Biochim Biophys Acta 2007. 1775:21-62.

111. Massague J: TGF[beta] in cancer. Cell 2008, 134:215-230,

112. Moustakas A, Kardassis D: Regulation of the human p21/WAF1/Cip1 promoter in hepatic cells by functional interactions between $\mathrm{Sp} 1$ and Smad family members. Proc Natl Acad Sci U S A 1998, 95:6733-6738.

113. Pardali K, Kurisaki A, Moren A, ten Dijke P, Kardassis D, Moustakas A: Role of Smad proteins and transcription factor Sp1 in p21Waf1/Cip1 Regulation by transforming growth factor-beta. J Biol Chem 2000, 275:29244-29256.

114. Koch RM, Roche NS, Parks WT, Ashcroft GS, Letterio JJ, Roberts AB: Incisional wound healing in transforming growth factor-beta1 null mice. Wound Repair Regen 2000, 8:179-191.

115. Ashcroft GS, Yang X, Glick AB, Weinstein M, Letterio JJ, Mizel DE, Anzano M, Greenwell-Wild T, Wahl SM, Deng C, Roberts AB: Mice lacking Smad3 show accelerated wound healing and an impaired local inflammatory response. Nat Cell Biol 1999, 1:260-266

116. Zhong Z, Tsukada S, Rehman H, Parsons CJ, Theruvath TP, Rippe RA, Brenner DA, Lemasters JJ: Inhibition of transforming growth factor-beta/Smad signaling improves regeneration of small-for-size rat liver grafts. Liver Transp/ 2010, 16:181-190.

117. Grose R, Werner S: Wound-healing studies in transgenic and knockout mice. Mol Biotechnol 2004, 28:147-166.

118. O'Kane S, Ferguson MWJ: Transforming growth factor [beta]s and wound healing. Int J Biochem Cell Biol 1997, 29:63-78,

119. Crowe MJ, Doetschman T, Greenhalgh DG: Delayed wound healing in immunodeficient TGF-[beta]1 knockout mice. J Invest Dermatol 2000, 115:3-11.

120. Xu G, Bochaton-Piallat ML, Andreutti D, Low RB, Gabbiani G, Neuville P: Regulation of alpha-smooth muscle actin and CRBP-1 expression by retinoic acid and TGFbeta-1 in cultured fibroblasts. J Cell Physio/ 2001, 187:315-325.

121. J.Shaw T, Kishi K, Mori R: Wound-associated skin fibrosis: mechanisms and treatments based on modulating the inflammatory response. Endocr Metab Immune Disord Drug Targets 2010, 10:320-330.

doi:10.1186/scrt71

Cite this article as: Arthur LM, Heber-Katz E: The role of p21 in regulating mammalian regeneration. Stem Cell Research \& Therapy 2011, 2:30. 